\title{
Selected results of determining the friction interaction coefficient between crushed stone and polyester strip
}

The Mining-Geology-Petroleum Engineering Bulletin UDC: $550.8: 55^{2.1}$

DOI: $10.17794 / \operatorname{rgn} .2017 \cdot 4 \cdot 4$

Original scientific paper

\author{
Karolina Gradiški'; Mensur Mulabdić ${ }^{\text {; }}$ Krunoslav Minažek ${ }^{2}$ \\ ${ }^{1}$ University of Zagreb, Faculty of Mining, Geology and Petroleum Engineering (Pierottijeva 6, HR-10000 Zagreb, Croatia, PhD Student) \\ ${ }^{2}$ Faculty of Civil Engineering Osijek (Vladimira Preloga 3, 31000 Osijek, Croatia, Full Professor) \\ ${ }^{3}$ Faculty of Civil Engineering Osijek (Vladimira Preloga 3, 31000 Osijek, Croatia, Assistant Professor)
}

\begin{abstract}
In the past twenty years in Croatia, a number of reinforced earth constructions have been built, of which two reinforced earth walls stand out due to their dimensions: Strikići and Sveta Trojica. In the building of these walls, polyester strips were used as reinforcement elements, whereas as fill material crushed stone aggregate was used. For designing these constructions, knowledge about the interaction mechanisms between the polyester strip and the soil is required. So far, most of the published studies have been directed to the determination of the friction interaction coefficient of the polyester strip and the fill material which was sand or gravel, whereas tests on the interaction between the geosynthetic strip and the crushed stone aggregate have not been performed. In order to determine the friction interaction coefficient between the crushed stone aggregate which is commonly used as fill material and the geosynthetic strip, pull-out tests of the polyester strip were carried out. Apart from pull-out tests, large direct shear tests were performed to determine shear strength parameters of crushed stone strength. Predictions from the numerical model were compared to a series of pull-out tests, proving that the numerical model provides reasonable predictions of pull-out behavior.
\end{abstract}

\section{Keywords}

Geosynthetic strip, crushed stone, pull-out test, large direct shear test, numerical analysis

\section{Introduction}

The concept of earth reinforcement is not new: the inclusion of reinforcements to improve the stability of soil structures has been used by man for centuries. The oldest examples of reinforced earth constructions are Ziggurat Agar-Quf and the Great Wall of China where fibrous plant, reed and wood materials were used as reinforcement. The modern concept of reinforced earth was invented by the French engineer Henry Vidal in the 1960s. Vidal developed a system of reinforced earth using flat reinforcing strips laid horizontally in frictional soil. He described this material as "Reinforced Earth" and that term has become generic in many countries, being used to describe all forms of reinforced soil structures (Jones, 1988). Another term used for "Reinforced Earth" structures is Mechanically Stabilized Earth (MSE) structures. Nowadays thousands of MSE structures have been built around the world using different reinforcement materials, such as metallic or plastic strips, bars, sheets and grids. Reinforced earth constructions are widely used in civil engineering, geotechnics and mining because of its aesthetics, flexibility, simple

Corresponding author: Karolina Gradiški e-mail address: karolina.gradiski@rgn.hr construction and the ability to adopt to different site conditions. Large settlements and differential rotations can be tolerated by reinforced soil without damage. A very common use of MSE is in the construction of gravity walls, where the wall is constructed using layers of compacted frictional fill materials with the reinforcement placed horizontally at suitable vertical intervals and tied to interlocking precast reinforced concrete panels (see Figure 1). The fill material must be a frictional to provide low deformability, drainage and adequate pull-out resistance between the soil and the reinforcement surface, whereby the reinforcement must have sufficient tensile stiffness. In comparison with conventional reinforced concrete walls for MSE walls savings of up to $20 \%-30 \%$ can be obtained, especially for heights over $5 \mathrm{~m}$ (Clayton et al., 2013).

In the past few years in Croatia, many MSE structure were built, but considering the dimension of construction two very tall walls can be selected, the Strikići (2006) and Sveta Trojica (2012) walls. The walls were built in the coastal region as part of a major highway construction project. To avoid metal in the construction of the wall (because of possible problems with corrosion - near sea area), strips made of polyester fibers coated with high density polyethylene were used as reinforcement. The backfill material was made of crushed rock 


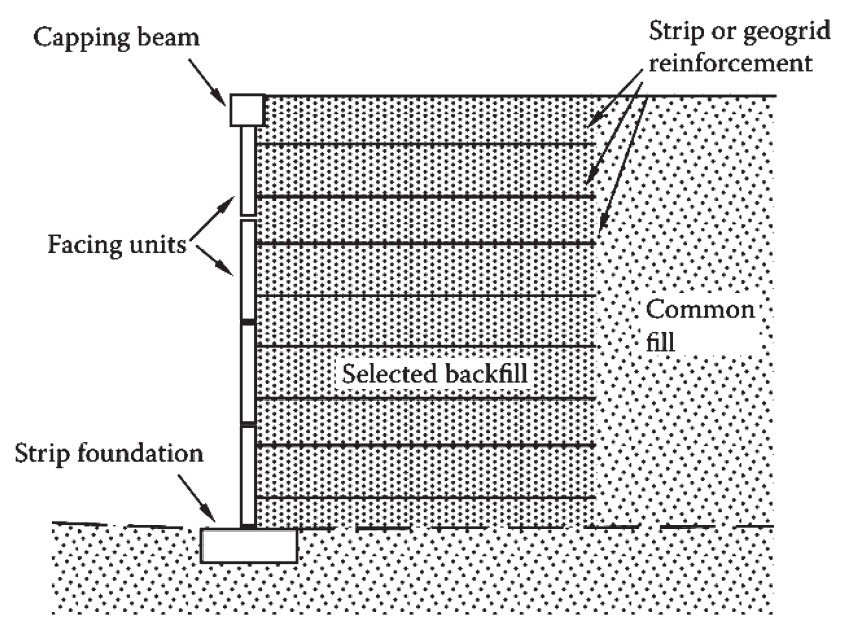

Figure 1: Section of Reinforced Earth (Clayton at al., 2013)

from the neighboring site and the wall facing was made of precast T-shaped reinforced concrete panels.

Basic design criteria for these two and all other reinforced earth structures demand the checking of external and internal stability. The checking of external stability is assessed in the same way as for conventional gravityretaining walls, whereas the checking of internal stability is unique for each type of structure. The internal stability of the reinforced zone must be checked with respect to tensile rupture of the reinforcement and pull-out failure between the fill and the reinforcement. Tensile failure depends on the tensile capacity in the reinforcement element. Pull-out failure depends on geometry and properties of the reinforcement, soil properties and the interaction between soil and reinforcement and it is often determined by pull-out tests.

The pull-out resistance of polyester strips and crushed stone aggregates is the subject of this research. Previous research of pull-out resistance of polyester strips was conducted for sand and gravel (Lo, 1998 and Abdelouhab et al., 2009, 2010); there is no information about pull-out tests with crushed stone aggregate and polyester strips. To understand the interaction mechanism between polyester strips and crushed stone aggregate better, information about mechanical properties of the soil (fric- tion angle, dilatancy and cohesion) and the results of the friction interaction coefficient from pull-out tests is required. To obtain information about mechanical properties of the soil, it is necessary to perform tests with the large direct shear testing (LDST) device, and to obtain information about the friction interaction coefficient, it is necessary to perform pull-out tests.

Performing large scale pull-out tests to investigate the interaction between the geosynthetic strip and the soil, as well as the influence of the boundary condition on the test results is a difficult and time-consuming task. Therefore, it is advisable to use the numerical method as a tool to improve the understanding about what factors influence the test results.

In this paper, the preliminary results of the experimental and numerical investigation of the interaction between a polyester strip and crushed stone aggregate together with the interaction coefficients obtained from tests are shown.

\section{Determination of the interaction coefficient}

The determination of the interaction coefficient included pull-out tests on strips and crushed stone aggregate, and large direct shear tests for the determination of the friction and dilatancy angle of crushed stone alone. Both of these types of tests were used in the experimental phase of the research, followed by an interaction investigation using FEM numerical analysis.

\subsection{Determination of interaction coefficient from pull-out test}

The pull-out resistance of the polyester strip and the crushed stone aggregate was investigated using a large pull-out testing device developed at the Faculty of Civil Engineering in Osijek, Croatia. A series of tests with different grain size distributions of crushed stone were carried out, and the interaction coefficients between the polyester strip and the crushed stone aggregate were determined (Gradiški et al., 2016).

\section{PULLOUT BOX \\ 4 CONTROL PANEL \\ 2 PISTON LOAD

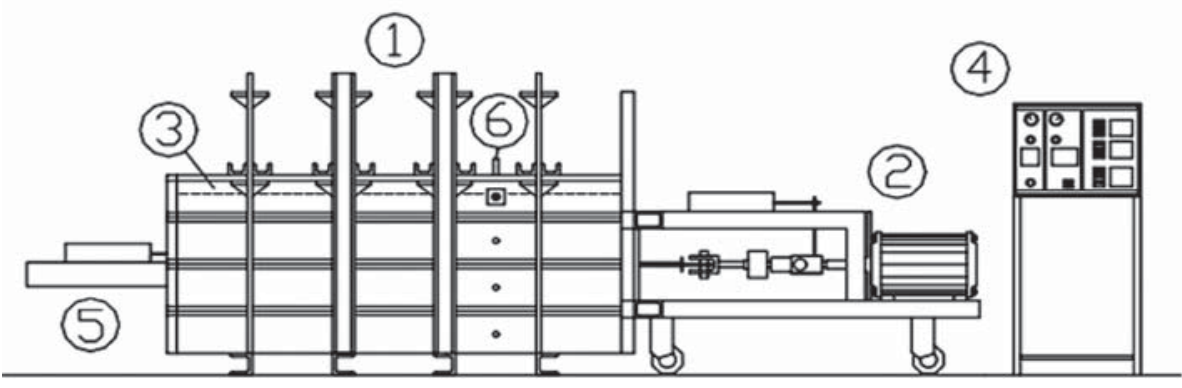

Figure 2: GFOS big pull-out testing device (Minažek, 2010) 


\subsection{1. $\Omega$ Testing equipment and program}

At the Faculty of Civil Engineering in Osijek, a large pull-out testing device (the GFOS pull-out device) was developed in 2002 (see Figure 2). The pull-out device consists of four $20 \mathrm{~cm}$ high horizontally set rectangular elements put one over the other and firmly framed, so that the size of the GFOS pull-out device is $\mathrm{L} \times \mathrm{B} \times \mathrm{H}=$ $1.9 \times 0.9 \times 1.2 \mathrm{~m}$ (Minažek \& Mulabdić, 2013). The impact of the front wall was reduced by a $25 \mathrm{~cm}$ wide sleeve at the front wall and through this sleeve a polyester strip was threaded. The strip was connected to the piston load by a specially equipped fixing system, consisting of five fastening plates around which the strip was wrapped.

The pull-out tests were carried out on a polyester strip placed on compacted crushed stone aggregate. The aggregate was placed in a box in $10 \mathrm{~cm}$ thick layers and compacted with a vibro-compactor until the height of 40 $\mathrm{cm}$ was reached after which the strip was placed at the center of the pull-out box. Four extensometers were used to monitor the displacements along the length of the polyester strip during pullout together with measurement of piston movement. The wires for extensometers were pulled through the metal protective tubes and the ends were attached to the strip at determined positions on the front, medium and rear part of the strip length. The pullout force was provided by a screw jack driven by an electric motor. Tests were carried out at a controlled displacement rate of $1 \mathrm{~mm}$ per minute and pullout force was measured by a load cell with a maximum capacity of $80 \mathrm{kN}$ (Gradiški et al., 2016). Normal stress was applied using airbags placed between the top of the fill and the cover plate. The tests were conducted with three different vertical stresses of $50 \mathrm{kPa}, 100 \mathrm{kPa}$ and $150 \mathrm{kPa}$.

\subsubsection{Materials used in testing}

The fill material used in the tests was crushed stone aggregate classified as GW according to ASTM D 24800 (2000). The material had 100\% passing the $75 \mathrm{~mm}$ sieve and approximately $5 \%$ passing the number 200 sieve. The material was compacted with a vibratory compactor.

The reinforcement element used in the tests was a strip made of discrete channels of closely packed high tenacity polyester fibers encased in a polyethylene sheath. In the test, strips with a tensile force of $100 \mathrm{kN}$ were used. The strip was $90 \mathrm{~mm}$ wide and $6 \mathrm{~mm}$ thick. The length of the strip inside the pull-out box was 1.65 $\mathrm{m}$, whereas the total length of the strip used in one test was more than $1.9 \mathrm{~m}$.

\subsubsection{Results of the pull-out tests}

The pull-out tests for the polyester strip and crushed stone aggregate were performed under three different

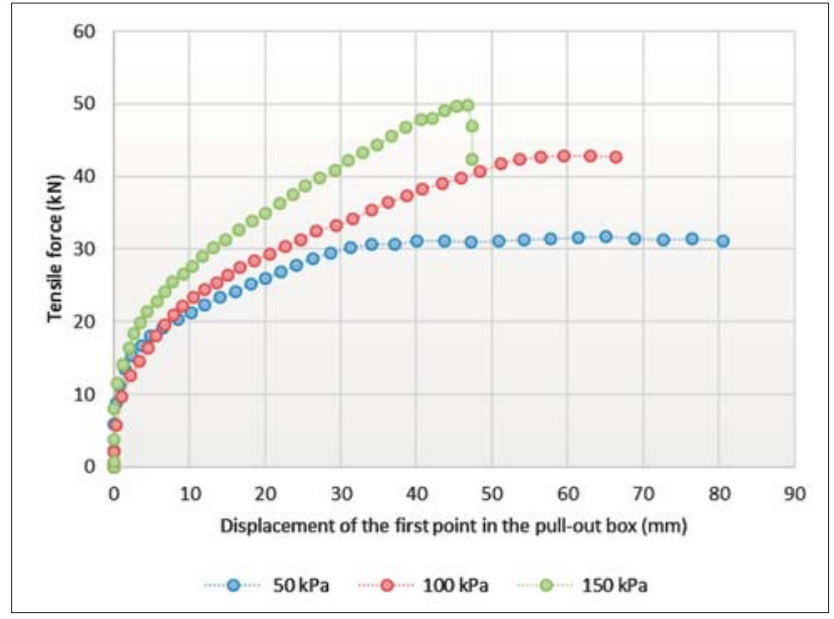

Figure 3: The displacement of the first point in the pull-out box under different confinement stresses

confinement stresses of $50 \mathrm{kPa}, 100 \mathrm{kPa}$ and $150 \mathrm{kPa}$. The test results showed an increase in the pull-out force with increased confinement pressure (see Figure 3).

The interaction coefficient is an important parameter in the calculations of stability of MSE structures. This parameter quantifies interaction (the adherence) of the reinforcement and the soil. In dense and dilatant granular soils, as the strip is being "pulled out", the soil in the vicinity of the strip will be subjected to considerable shearing. Shearing will lead to volumetric dilation when the granular soil is in a well-compacted state. However, this dilatancy of the soil in the vicinity of the strip is constrained, leading to an increase in the normal stress, $\sigma_{n}$ and acting directly on the strip up to a value which exceeds the average overburden stress acting on the surrounding soil $(\mathbf{L o}, \mathbf{1 9 9 8})$. The vertical stress applied on the strip becomes:

$$
\sigma_{v}=\sigma_{v 0}+\Delta \sigma_{v}
$$

This phenomenon is named constrained dilatancy (Abdelouhab et al. 2010) and the real friction coefficient, $f$ is expressed:

$$
f=\frac{\tau_{\max }}{\sigma_{v 0}+\Delta \sigma_{v}}
$$

To include this phenomenon and the influence of dilatancy in the design procedure, Schlosser and Bastick (1991) defined the interaction coefficient $f_{\mathrm{S} / \mathrm{GSY}}$ :

$$
f_{S / G S Y}=f \frac{\sigma_{v 0}+\Delta \sigma_{v}}{\sigma_{v 0}}
$$

Where:

$f-$ true coefficient of friction between soil and reinforcement

$\Delta \sigma_{v}$-increase of normal stress on the reinforcement due to restrained dilatancy.

Since in this research the $\Delta \sigma_{v}$ around the strip was not measurable during the pull-out test, the friction interac- 
tion coefficient was calculated according to the formula given by Schlosser and Elias (1978) related to the apparent friction coefficient:

$$
f_{S / G S y}=\frac{P_{\max }}{\sigma_{v} 2 l b}
$$

Where:

$P_{\max }$ - maximum tensile force measured at the head of reinforcement $(\mathrm{kN})$

$\sigma_{v}$ - normal effective stress acting in the vertical direction at the reinforcing strip $(\mathrm{kPa})$

$b \quad$ - reinforcement width (m)

$l \quad$ - reinforcement length $(\mathrm{m})$.

The test results of the apparent friction interaction coefficient decrease as the confinement stress increases (see Figure 4).

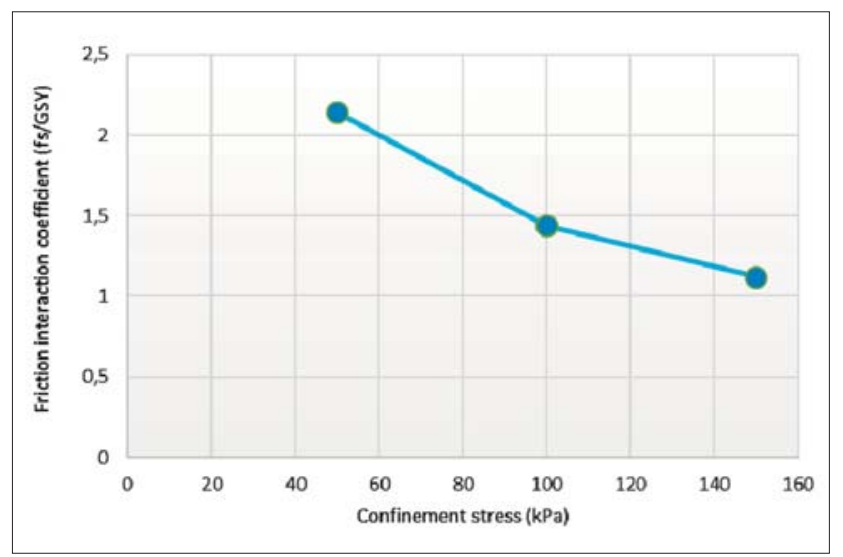

Figure 4: The apparent friction interaction coefficient for polyester strip and crushed stone aggregate

\subsection{Determination of friction angle and dilatancy of crushed stone aggregate from large direct shear testing}

The large direct shear testing (LDST) device was developed at the Faculty of Mining Geology and Petroleum Engineering in Zagreb for direct shear testing of materials with a relatively large particle size, which cannot be tested with standard testing devices. The LDST device was developed in order to facilitate the testing of coarse/aggregate materials like gravel and crushed stone or materials obtained by recycling. The development of the device was partially financially supported by the University of Zagreb and mainly by the Geomechanical laboratory of the Faculty of Mining, Geology and Petroleum Engineering.

The LDST device consists of a main steel frame, large shear box, two hydraulic columns, SBEL servo and an electrical hydraulic pump and computer based measurement system, as seen in Figure 5. Special attention was paid to the construction of the large shear box and the development of the computer-based measurement sys-

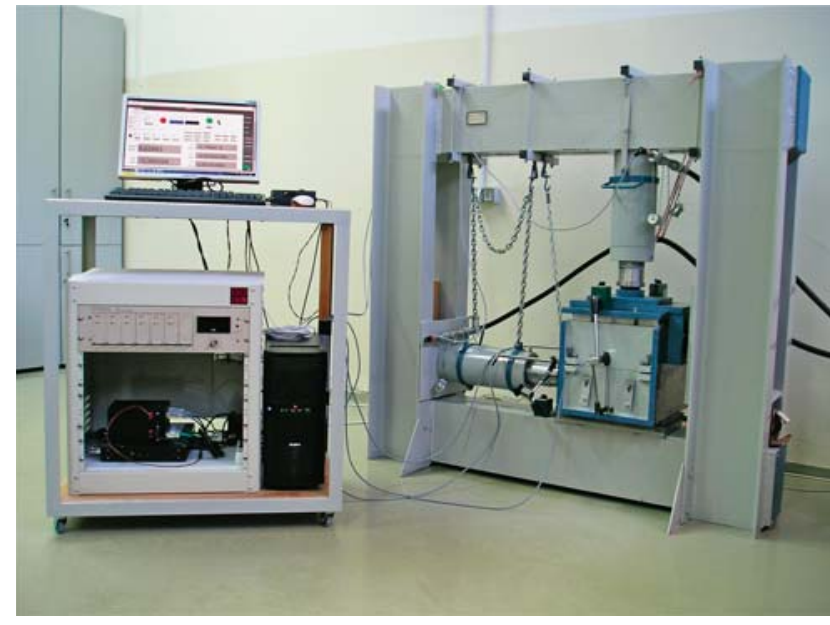

Figure 5: Large direct shear testing (LDST) developed at the Faculty of Mining, Geology and Petroleum Engineering

tem. The large shear box has dimensions for the preparation of samples of $300 \times 300 \times 300 \mathrm{~mm}$. The computerbased measurement system consists of the National Instruments LabVIEW computer program, data acquisition and signal conditioning system as well as displacement and pressure transducers.

\subsubsection{Material used in testing}

The fill material used in pull-out tests was well-graded crushed stone aggregate. The material used in the large direct shear test is classified as GW according to ASTM D 248-00 (2000). Since the dimension of the direct shear box is $300 \times 300 \times 300 \mathrm{~mm}$, the maximum particle size was limited to $31.5 \mathrm{~mm}$. In the pull-out test, material with a maximum grain size of $60 \mathrm{~mm}$ was used, and in the large direct shear test a scalped sample, from which particles larger than $31,5 \mathrm{~mm}$ had been removed, was used. The coefficient of uniformity, $C_{u}$ was 9.82 , and $D_{60}$ was $4.681 \mathrm{~mm}$. The material was weighed before being placed inside the shear box, and the density was determined for each specimen. The density ranged between $2140 \mathrm{~kg} / \mathrm{m}^{3}$ and $2163 \mathrm{~kg} / \mathrm{m}^{3}$.

\subsubsection{Results of testing}

The direct shear tests of crushed stone aggregate were performed under three different normal stresses: $85 \mathrm{kN} /$ $\mathrm{m}^{2}, 150 \mathrm{kN} / \mathrm{m}^{2}$ and $215 \mathrm{kN} / \mathrm{m}^{2}$, whereas the shear stress was measured as a function of shear displacement. The secant friction angle for each specimen is calculated using the arctangent function of shear and normal stress ratio at the failure. The dilatancy angle is determined by applying the method of least square from the vertical displacement versus the horizontal displacement curve. The highest friction angle was determined for the lowest normal stress $\left(85 \mathrm{kN} / \mathrm{m}^{2}\right)$, and the lowest friction angle was determined for a normal stress of $215 \mathrm{kN} / \mathrm{m}^{2}$. The determined friction angles and dilatancy angles are presented in Table 1. 
Table 1: Secant friction angle and dilatancy for crushed stone aggregate

\begin{tabular}{|l|c|c|}
\hline $\begin{array}{l}\text { Normal stress } \\
\mathrm{kN} / \mathrm{m}^{2}\end{array}$ & $\begin{array}{c}\text { Secant friction angle } \\
\left({ }^{\circ}\right)\end{array}$ & $\begin{array}{c}\text { Dilatancy } \\
\left({ }^{\circ}\right)\end{array}$ \\
\hline 85 & 51.1 & 13.5 \\
\hline 150 & 47.9 & 9.8 \\
\hline 215 & 42.7 & 11.3 \\
\hline
\end{tabular}

\section{Finite element analysis}

In the pull-out tests, the deformations are highest at the leading part of the strip, reducing towards the rear of the strip. The pull-out force developed along the reinforcement mobilizes development of shear stresses in the soil, and as a consequence, the magnitudes and directions of the principal stresses in the soil are being continuously altered (Yogarajah \& Yeo, 1994). Additional complication in the interpretation of the results arises from-the stress-strain properties of the material, when polymeric reinforcements are used. This complex behavior makes the interpretation of pull-out results very difficult (Yogarajah \& Yeo, 1994). Numerical modeling can be very useful for overcoming this problem when analyzing the pull-out behavior of strip reinforcement in the soil. The very often used Plaxis software has proven to be a powerful and accurate tool to predict pull-out test results (Bergado et al., 2003, Abdi \& Zandieh, 2014, Yu et al., 2015, Sukmak et al., 2016). Thus, the finite element program Plaxis was used in the present study to simulate the pull-out test for a polyester strip and crushed stone aggregate. The finite element analysis was performed in plane strain conditions using 15 node triangular elements and each element contains 12 stress points.

\subsection{Geometry of the model}

To simulate the pull-out test in the numerical analysis, the pull-out box was modeled similar to the actual size of the test box (see Figure 6) with dimensions L x B x H $=1.65 \times 0.9 \times 0.7$. Since the box was made of metal plates, it was reasonable to assume that soil particles cannot move in the direction perpendicular to the boundary, so the bottom boundary was modeled by total fixity, and side boundary was fixed in the $\mathrm{x}$-direction. The reinforcement, however, was allowed to move freely in the $\mathrm{x}$ - direction, whereas the displacement was simulated as horizontal nodal displacement at the leading edge of the strip. Displacement in the $\mathrm{y}$ - direction of the leading part was constrained and displacement was applied in the $\mathrm{x}$-direction, which matches the conditions presented in the pull-out test. Normal pressure was applied on the top surface of the soil by a uniformly distributed load.

\subsection{Material models and parameters}

The soil material used in pull-out tests was crushed stone aggregate, and in the numerical model it was modeled as a linearly elastic-perfectly plastic material with the Mohr-Coulomb (MC) failure criteria. The MC model requires a total of five parameters: Young's modulus $(E)$, Poisson's ratio (v), cohesion $(c)$, internal friction angle $(\varphi)$ and dilatancy angle $(\psi)$ (Plaxis 2016). These parameters are familiar to most geotechnical engineers and can be obtained through basic tests on soil samples. The internal friction angle and dilatancy angle were determined using large direct shear tests and pull-out tests. Douglas (2002) stated that the secant friction angle is most commonly quoted when test results are published. In the present analysis, the secant friction angle for the crushed stone aggregate was used. The secant friction angle was given for three different confining stresses of $50 \mathrm{kPa}$ (referred to as C1), $100 \mathrm{kPa}$ (referred to as C2) and $150 \mathrm{kPa}$ (referred to as C3). Young's modulus was determined from in situ plate load tests on similar materials. The material properties of the crushed stone aggregate used in the test are shown in Table 1. The strip was simulated using Geogrid elements that are slender structures with axial stiffness but no bending stiffness. The basic material property for the Geogrid element is the axial stiffness EA (Plaxis, 2016), which was evaluated from Young's modulus of the strip $2500 \mathrm{MPa}$ and the transversal area of strip with a width of $90 \mathrm{~mm}$ and a thickness of $6 \mathrm{~mm}$. The interaction between the soil and Ge-
Figure 6: Geometrical model in the Plaxis 2D 2016

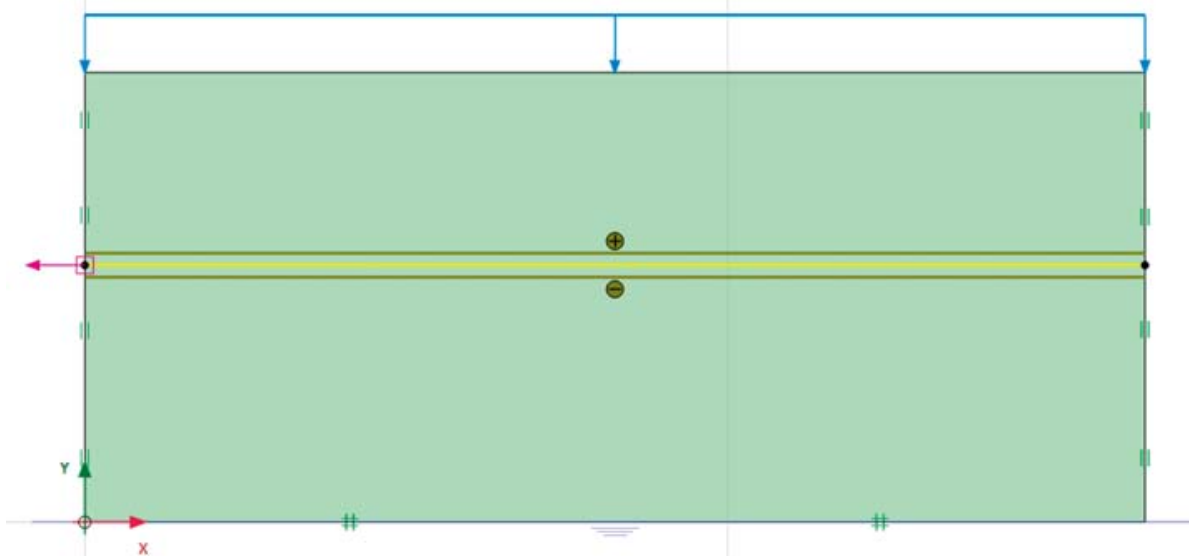


ogrid element was modeled by Interface element. These elements have the properties of Young's modulus $(E)$, Poisson's ratio $(v)$, friction angle $(\varphi)$, dilatancy $(\psi)$ and cohesion $(c)$. The value of the interface element can be set using two options: a) by the reduction factor $\left(R_{i n t}\right)$ applied to the soil material when defining soil properties and b) by defining different soil properties for the interface element. When the option of reduction soil properties $R_{\text {int }}$ is selected, it is only possible to define values equal to soil properties or lower $\left(R_{\text {int }} \leq 1.0\right)$. In this analysis, the friction angle for material was increased to the value determined in the pull-out test. The dilatancy was determined from the relation recommended by Plaxis (2016), where dilatancy $(\psi)$ is equal to the friction angle $(\varphi)$ minus $30^{\circ}$. Material parameters used in the analysis are presented in Table 2.

Table 2: Model parameters for crushed stone aggregate

\begin{tabular}{|l|l|c|c|c|}
\hline Parameter & Unit & $\begin{array}{c}\mathrm{C} 1 \\
(50 \mathrm{kPa})\end{array}$ & $\begin{array}{c}\mathrm{C} 2 \\
(100 \mathrm{kPa})\end{array}$ & $\begin{array}{c}\mathrm{C} 3 \\
(150 \mathrm{kPa})\end{array}$ \\
\hline Material model & - & $\mathrm{MC}$ & $\mathrm{MC}$ & $\mathrm{MC}$ \\
\hline $\begin{array}{l}\text { Young's modulus } \\
(E)\end{array}$ & $\mathrm{kN} / \mathrm{m}^{2}$ & 70000 & 70000 & 70000 \\
\hline $\begin{array}{l}\text { Poisson's ratio } \\
(v)\end{array}$ & - & 0.35 & 0.35 & 0.35 \\
\hline Cohesion $(c)$ & $\mathrm{kN} / \mathrm{m}^{2}$ & 0.1 & 0.1 & 0.1 \\
\hline Friction angle $(\varphi)$ & $\circ$ & 65 & 55 & 49 \\
\hline $\begin{array}{l}\text { Dilatancy angle } \\
(\psi)\end{array}$ & $\circ$ & 35 & 25 & 20 \\
\hline
\end{tabular}

\subsection{Results of analysis}

Numerical analyses were performed to simulate real pull-out tests with a polyester strip and crushed stone aggregate. The results of numerical analyses showed

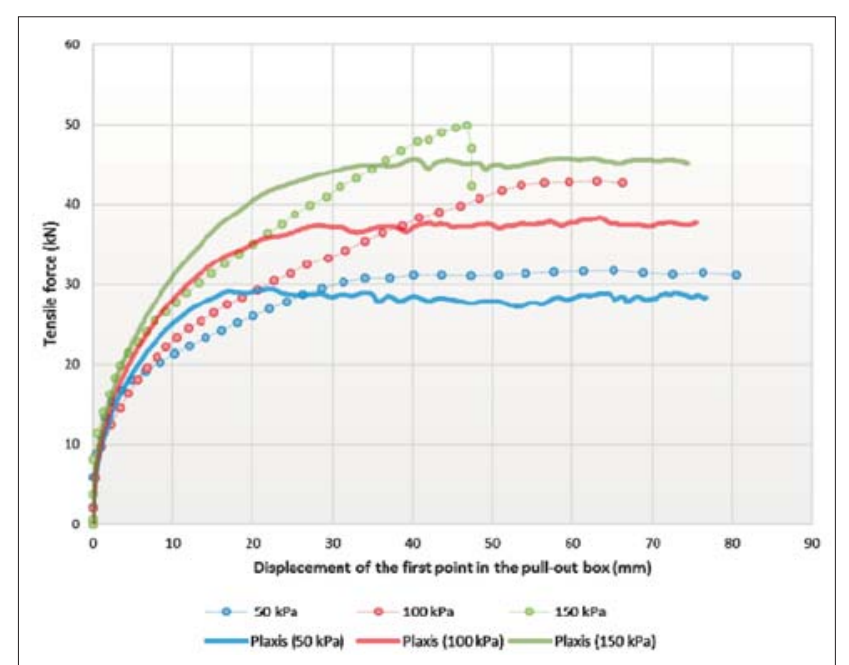

Figure 7: Pull-out force/displacement curve of polyester strip in crushed stone aggregate when comparing pull-out test and Plaxis good agreement with the measured data. The tensile force determined through numerical analyses is slightly lower than the measured, see Figure 7. In the Plaxis 2D it is impossible to model the effect of constrained dilatancy which takes place in real pull-out force, which explains the lower pull-out force in the numerical analyses.

\section{Conclusion}

In the experimental part of the study presented in this paper, the interface behavior of the polyester strip and crushed stone under various confinement stresses was measured and analyzed. The results of the experimental study show that the friction angle on the interface strip/ soil is higher than the friction angle of the soil alone, resulting in interaction coefficients which have values significantly higher than 1.0 for the lower values of confinement stress. The results also show that the interaction coefficient between the strip reinforcement and crushed stone aggregate decreases as confinement stress increases towards the value of 1.0 (for the confinement stress of $150 \mathrm{kPa}$ ). The results of laboratory pull-out tests and numerical simulations were also compared. The results of the numerical study show a slightly lower tensile force that can be explained by the effect of constrained dilatancy which is impossible to model in the $2 \mathrm{D}$ model. The pull-out of the polyester strip is a threedimensional problem, so that for a more accurate numerical analysis, it is advisable to perform the 3D numerical analysis.

\section{References}

Abdelouhab A., Dias D., Freitag N. (2009): Pull-out behaviour of geosynthetic strip reinforcements in coarse fill physical and analytical modelling. GIGSA GeoAfrica 2009 Conference 2 - 5 September 2009, 1-9.

Abdelouhab, A., Dias, D., Freitag, N. (2010): Physical and analytical modelling of geosynthetic strip pull-out behaviour. Geotextiles and Geomembranes, 28, 44-53.

Abdi, M.R., Zandieh, A.R. (2014): Experimental and numerical analysis of large scale pull out tests conducted on clays reinforced with geogrids encapsulated with coarse material. Geotextiles and Geomembranes, 42, 494-504.

ASTM D 248-00 (2000): Standard Practice for Classification of Soil for Engineering Purpose (Unified Soil Classification System), ASTM International, West Conshohocken, PA, www.astm.org, p. 1-12.

Bergado, D.T., Youwai, S., Teerawattanasuk, C., Visudmedanukul, P. (2003): The interaction mechanism and behaviour of hexagonal wire mesh reinforced embankment with silty sand backfill on soft clay. Computers and Geotechnics, 30, 517-534.

Brinkgreve, R.B.J., Kumarswamy, S., Swolfs, W.M. (2016): PLAXIS User's Manual, Delft University of Technology and PLAXIS BV, Netherlands. 
Clayton, C.R.I., Woods, R.I., Bond, A.J. Milititsky, J. (2013): Earth Pressure and Earth-retaining Structures. Third Edition. Taylor \& Francis Group, Boca Raton, 608 p.

Douglas, K.J. (2002): The shear strength of rock masses. Thesis. School of Civil and Environmental Engineering. The University of New South Wales, Sydney, Australia, $545 \mathrm{p}$.

Gradiški, K., Minažek, K., Mulabdić, M., Kvasnička, P. (2016): Preliminary results of soil - geosynthetic strip interaction in pullout. 6th European Geosynthetics Congress, Ljubljana, 1052-1060.

Jones, C.J.F.P. (1985): Earth Reinforcement and Soil Structures. University of Newcastle upon Tyne, UK: Butterworth-Heinemann, $210 \mathrm{p}$.

Lo, S.C.R. (1998): Pull-out resistance of polyester straps at low overburden stress. Geosynthetics International, 5(4), 361-382.

Minažek, K. (2010): Modelsko ispitivanje interakcije geomreže i tla (Model testing of Geogrid-soil Interaction). Doctoral dissertation. University of Zagreb, Faculty of Civil Engineering, 296 p. (In Croatian)
Minažek, K. and Mulabdić, M. (2013): A review of soil and reinforcement interaction testing in reinforced soil by pullout test. Građevinar, 65 (3), 235-250.

Schlosser, F. \& Elias, V. (1978): Friction in Reinforced Earth, Symposium on Earth Reinforcement, A.S.C.E. Pittsburgh, April 24-28., 735-763.

Schlosser, F., Bastick, M. (1991): Reinforced Earth. In: Fang, H-Y. (eds.): Foundation Engineering Handbook Second Edition: Reinforced Earth. Springer Science + Business Media $778-795 \mathrm{p}$.

Sukmak, K., Han, J., Sukmak, P., Horpibulsuk, S. (2016): Numerical parametric study on behaviour of bearing reinforcement earth walls with different backfill material properties. Geosynthetics International, 23 (6), 435-451.

Yorgajah, I. \& Yeo, K.C. (1994): Finite Element Modelling of Pull-Out Tests with Load and Strain Measurements. Geotextiles and Geomembranes, 13, 45-54.

Yu, Y., Damians, I.P., Bathurst, R.J. (2015): Influence of choice of FLAC and PLAXIS interface models on reinforced soilstructure interactions. Computers and Geotechnics, 65, 164-174.

\section{SAŽETAK}

\section{Preliminarni rezultati određivanja koeficijenta interakcije lomljenoga kamena i poliesterske trake}

U Hrvatskoj je u posljednjih dvadesetak godina izgrađeno više konstrukcija od armiranoga tla, pri čemu se po svojim dimenzijama ističu dva zida od armiranoga tla, Strikići i Sveta Trojica. U gradnji tih zidova kao armaturni elementi korištene su poliesterske trake, dok je kao materijal ispune korišten lomljeni kamen. Za projektiranje takvih konstrukcija potrebno je poznavanje mehanizma interakcije između poliesterske trake i tla. Dosadašnja ispitivanja koja su bila usmjerena na određivanje koeficijenta interakcije poliesterske trake i tla provedena su za slučajeve kada je kao materijal ispune korišten pijesak ili šljunak, dok ispitivanja interakcije armaturne trake i lomljenoga kamena nisu provedena. Kako bi se odredili koeficijenti interakcije između lomljenoga kamena i poliesterske trake provedena su ispitivanja izvlačenja poliesterske trake i lomljenoga kamena različitoga granulometrijskog sastava. Uz ispitivanja izvlačenja provedena su i ispitivanja izravnoga smicanja kako bi se odredili parametri čvrstoće lomljenoga kamena, a rezultati laboratorijskih ispitivanja korišteni su za provedbu numeričkih analiza izvlačenja trake iz tla.

\section{Ključne riječi:}

poliesterska traka, lomljeni kamen, ispitivanje izvlačenja, veliki izravni posmik, numeričke analize

\section{Author(s) contribution}

Karolina Gradiški and Mensur Mulabdić wrote the article and analysed the results of laboratory pullout test as well as the results of the numerical calculations. The main contribution of Krunoslav Minažek was the performance of all laboratory pullout tests and the analysis of test results. 